\title{
Improving Cancer Immunotherapy by Targeting the Hypoxic Tumor Microenvironment: New Opportunities and Challenges
}

\author{
Muhammad Zaeem Noman ${ }^{1}$, Meriem Hasmim ${ }^{1}$, Audrey Lequeux ${ }^{1}{ }^{\circledR}$, Malina Xiao ${ }^{1}$, \\ Caroline Duhem ${ }^{2}$, Salem Chouaib ${ }^{3,4}$, Guy Berchem ${ }^{1,2}$ (1) and Bassam Janji ${ }^{1, *}$ \\ 1 Tumor Immunotherapy and Microenvironment (TIME) Group, Department of Oncology, \\ Luxembourg Institute of Health, Luxembourg, L-1526 Luxembourg City, Luxembourg; \\ MuhammadZaeem.Noman@lih.lu (M.Z.N.); Meriem.Hasmim@lih.lu (M.H.); \\ audrey.lequeux@lih.lu (A.L.); malina.xiao@lih.lu (M.X.); berchem.guy@chl.lu (G.B.) \\ 2 Centre Hospitalier du Luxembourg, Department of Hemato-Oncology, L-1526 Luxembourg City, \\ Luxembourg; Duhem.Caroline@chl.lu \\ 3 INSERM U1186, Gustave Roussy Cancer Center, 94805 Villejuif, France; salem.chouaib@gustaveroussy.fr \\ 4 Thumbay Research Institute for Precision Medicine - Gulf Medical University, 4184 Ajman, UAE \\ * Correspondence: bassam.janji@lih.lu; Tel.: +352-26-970-285
}

Received: 24 July 2019; Accepted: 12 September 2019; Published: 14 September 2019

\begin{abstract}
Initially believed to be a disease of deregulated cellular and genetic expression, cancer is now also considered a disease of the tumor microenvironment. Over the past two decades, significant and rapid progress has been made to understand the complexity of the tumor microenvironment and its contribution to shaping the response to various anti-cancer therapies, including immunotherapy. Nevertheless, it has become clear that the tumor microenvironment is one of the main hallmarks of cancer. Therefore, a major challenge is to identify key druggable factors and pathways in the tumor microenvironment that can be manipulated to improve the efficacy of current cancer therapies. Among the different tumor microenvironmental factors, this review will focus on hypoxia as a key process that evolved in the tumor microenvironment. We will briefly describe our current understanding of the molecular mechanisms by which hypoxia negatively affects tumor immunity and shapes the anti-tumor immune response. We believe that such understanding will provide insight into the therapeutic value of targeting hypoxia and assist in the design of innovative combination approaches to improve the efficacy of current cancer therapies, including immunotherapy.
\end{abstract}

Keywords: hypoxia; HIF; tumor microenvironment; immune checkpoints; immunotherapy; autophagy

\section{Introduction}

During the last two decades, the majority of cancer immunotherapies designed by immunologists have mainly focused on potentiating $\mathrm{T}$ lymphocyte-mediated anti-tumor adaptive immunity. Strategies based on systemic treatments using interleukin 2 (IL-2) [1] or infusion of autologous T lymphocytes [2] were tested with minor or no therapeutic success, combined with high toxicities. In the last 5 years, immunotherapy approaches using single immune checkpoint blockade (ICB) agents have shown striking clinical efficacy in diverse cancers [3]. ICB-based cancer immunotherapies, notably the T cell immune checkpoint inhibitors anti-cytotoxic T lymphocyte associated protein 4 (CTLA-4) and the anti-programmed cell death protein 1 (PD-1), have provided durable clinical benefit in diverse cancer patients [4]. ICBs hold much promise for the treatment of multiple cancers, including breast, lung, kidney, bladder, prostate cancers, lymphoma, and melanoma [5]. In 2011, the U.S. Food and Drug Administration (FDA) approved ipilimumab (anti-CTLA-4) for the treatment of advanced melanoma, 
followed by pembrolizumab and nivolumab (anti-PD-1) in 2014. The durable clinical responses observed in patients [4] were largely attributed to the fact that ICB removes inhibitory signals or potentiate stimulatory signals on cytotoxic $\mathrm{T}$ lymphocytes rather than targeting tumor cells [4].

However, despite the exciting and promising clinical responses in diverse malignancies, the early promising results obtained using ICB-based monotherapies (anti-CTLA-4, anti-PD-1, or anti-PD-L1) have been seriously compromised by clinical data showing that the majority of ICB-treated patients have incomplete responses and that they fail to achieve higher objective responses. Indeed, the majority of patients treated with ICBs only reaps a short-term benefit or no benefit at all [6]. Briefly, ICB-based therapy is still in its early stages for breast cancer. Both anti-PD-1 and -PD-L1 induce response rates of $19 \%$ in patients with heavily pre-treated, chemotherapy-resistant, PD-L1-positive, triple-negative breast cancers (TNBCs) [7]. This clearly shows that the majority of patients (81\%) with PD-L1-positive TNBC are completely refractory to ICB, most likely due to tumor adaptation to innate and adaptive immunity. In clear cell renal cell carcinomas (ccRCC), which represent almost $70 \%$ of all kidney cancers, it has been reported that the anti-PD-1 nivolumab improved the overall survival and overall objective response rate of patients who had prior antiangiogenic therapy [8]. However, no improvement of progression-free survival was observed with anti-PD-1 therapy [9]. In melanoma, it has also been reported that single treatment with anti-CTLA4 or anti-PD-1 antibodies yielded modest clinical benefit. However, combined therapy with both anti-PD-1 and anti-CTL-A4 significantly improves patient survival [10,11].

There is circumstantial evidence indicating that combination approaches improve the efficacy of ICB monotherapies [6]. The efficacy of combination approaches relies on the ability to: (i) increase the tumor infiltration of major cytotoxic immune cells into the tumor bed; (ii) limit the trafficking and function of immune suppressive cells (regulatory $\mathrm{T}$ cells, pro-tumoral macrophages and/or myeloid-derived suppressor cells (MDSC)); and (iii) promote the release and presentation of tumor-associated antigens to further potentiate $\mathrm{T}$ cell activation. In the design of novel synergistic combinations, we believe that the following questions need to be addressed: (1) What to combine? There is circumstantial evidence suggesting that innovative combination approaches will not be restricted to the use of ICBs, but will include agents that directly target signaling pathways in cancer cells themselves to improve the anti-tumor immune response [12]; (2) How to combine? It has been reported that an increased efficacy was observed when concomitantly inhibiting CTLA-4 and PD-1 pathways relative to inhibition of CTLA-4 or PD-1 alone or sequentially [13]. Therefore, the schedule of administering ICB therapies needs to be carefully considered; and (3) When to combine? It is now well supported that driving a sustained anti-tumor immune response relies on the successful infiltration of immune cells into the tumor bed and the expression of different immune checkpoints and their ligands [14].

It should be noted that although combinatorial approaches held considerable promise [4], the potential added risk of toxicity needs to be considered and carefully evaluated in the clinic. Therefore, a safe, robust, and smart combination should be designed in order to extend the clinical benefit of cancer immunotherapy to a larger proportion of cancer patients and tumor types.

It is also important to keep in mind that an optimal combination strategy should consider the fact that different cells in the tumor microenvironment (tumor cells, stromal cells, and different immune cells) can simultaneously express different levels of diverse immune checkpoints [4,5]. A better understanding of the interactions between the tumor microenvironment and the immune system is crucial for developing new combination strategies. In this review, we will briefly describe the impact of hypoxia as a major tumor microenvironmental factor in regulating the anti-tumor immune response and provide some clues on how targeting hypoxia could improve the therapeutic benefit of cancer immunotherapy.

\section{The Mechanisms Underlying the Establishment of Hypoxic Tumor Microenvironment and the Impact of Hypoxia on Damping the Anti-Tumor Immune Response}

Hypoxia in the tumor microenvironment refers to a condition where the pressure of oxygen is lower than 5-10 $\mathrm{mm} \mathrm{Hg}$. Therefore, hypoxic regions in the tumors arise from (i) the increase in oxygen 
consumption due to a marked augmentation in tumor cell proliferation [15], and (ii) the inadequate oxygen supply to the cells and tissues due to the establishment of chaotic tumor microvasculature network with leaky vessels that often fail to rectify the oxygen deficit [16] (Figure 1A).

The hypoxia-inducible factor (HIF) family of transcription factors are well-defined factors allowing tumor cell adaptation to the hypoxic microenvironment. Three members of the HIF family have been identified: HIF- $1 \alpha$, HIF- $2 \alpha$, and HIF-3 $\alpha$ [17]. HIF- $1 \alpha$ is a well-described factor involved in the adaptive responses to tissue oxygen level changes [18]. While the expression of HIF-1 $\alpha$ in cells occurred in an $\mathrm{O}_{2}$-independent manner, its degradation predominantly occurred in an $\mathrm{O}_{2}$-dependent mechanism. Under normoxic conditions, HIF- $1 \alpha$ is constantly expressed but rapidly degraded by the ubiquitin-proteasome system (in less than $5 \mathrm{~min}$ ) [19]. However, under hypoxia, the degradation of HIF- $1 \alpha$ is blocked, which results in HIF- $1 \alpha$ accumulation. The cytoplasmic accumulation of HIF- $1 \alpha$ leads to its translocation to the nucleus and the formation of a heterodimer with HIF-1 $\beta$. Finally, the heterodimer HIF- $1 \alpha / \mathrm{HIF}-1 \beta$ binds to the hypoxia-responsive element (HRE) in target genes and activates the transcription of several genes involved in various cellular pathways, including autophagy [20].

Hypoxic tumor microenvironment is therefore considered a major mechanism responsible for tumor resistance to several therapies, including chemotherapy and radiotherapy [21,22]. While the major role of hypoxia on chemotherapy and radiotherapy resistance is now well known and extensively reported [23], emerging new data points to hypoxia as a major factor contributing to tumor resistance to immunotherapy $[24,25]$. This is supported by preclinical and clinical data indicating that the majority of mechanisms overwhelming the antitumor immunity were directly evolved from the hypoxic tumor microenvironment [26]. We and others have reported that hypoxia dramatically impaired the anti-tumor immune response [27-29]. Indeed, the hypoxic area of the solid tumor is poorly infiltrated by anti-tumor immune cells. Even if anti-tumor immune cells reach the hypoxic tumor microenvironment, they may not be able to exert their tumor-killing function. Moreover, it has been reported that factors derived from malignant cells participate in the anergic phenotype properties of immune cells in the tumor stroma [30]. Furthermore, anti-tumor immune cells in the tumor microenvironment not only fail to achieve their killing functions but are also co-opted to promote tumor growth [31].

\section{Hypoxia Upregulates the Expression of PD-L1 and Promotes the Establishment of the Immunosuppressive Tumor Microenvironment}

PD-1 is an inhibitory receptor expressed on activated T lymphocytes and other immune cells [32]. The expression of PD-1 leads to T cell exhaustion following its binding to two ligands, programmed death ligand 1 and 2 (PD-L1 and PD-L2). Thus, the interaction between PD- 1 and its ligands provides a negative signal to $\mathrm{T}$ cells, which ultimately blocks their cytotoxic functions [4]. The molecular mechanism(s) underlying the expression of PD-L1 in different tumor types have been extensively investigated. Hypoxia, via HIF-1 $\alpha$, directly up-regulates the expression of PD-L1 in various tumor cells (melanoma, lung, breast and prostate cancer) by directly binding the HRE in the promoter of PD-L1 gene $[33,34]$. HIF-2 $\alpha$ is also involved in PD-L1 induction in ccRCC. The mutation of the VHL gene induced HIF- $2 \alpha$ stabilization in ccRCC cells. Stabilized HIF- $2 \alpha$ led to the upregulation of PD-L1 in vitro. Furthermore, in ccRCC patients, the mutation status of VHL was associated with HIF- $2 \alpha$ stabilization. Such stabilization was strikingly correlated with an increased expression of PD-L1 [35]. In immune cells, such as MDSCs and macrophages, HIF- $1 \alpha$ selectively upregulates the expression of PD-L1. MDSCs displaying high expression levels of PD-L1 negatively impact the functions of cytotoxic T lymphocytes (CTL). Blocking PD-L1 abrogated MDSC-mediated T cell suppression [33,36] (Figure 1B).

\section{Hypoxia Induces the Expression of the Immune Checkpoint V-Domain Ig Suppressor of T Cell Activation (VISTA) and Promotes the Immunosuppressive Function of Tumoral MDSC}

In addition to PD-L1, it has been recently shown that VISTA is overexpressed in the hypoxic areas of colon cancer patients and CT-26 colon mouse model [37]. Indeed, VISTA was preferentially 
expressed on myeloid cells, namely CD11 $\mathrm{b}^{\text {high }} \mathrm{CD} 11 \mathrm{c}^{+}$dendritic cells, CD11b $\mathrm{b}^{\text {high }} \mathrm{F} 4 / 80^{+}$macrophages, with the highest expression on $\mathrm{CD} 11 \mathrm{~b}^{\text {high }} \mathrm{Gr} 1^{+}$MDSCs infiltrating the hypoxic areas of the tumor (Figure 1B). The infiltration of MDSCs from the periphery to the hypoxic area of the tumor is associated with the hypoxia-dependent increase in the expression of stromal-derived factor 1 (SDF1, CXCL12) [38]. Furthermore, the upregulated expression of VISTA under hypoxia was attributed to the ability of HIF- $1 \alpha$, but not HIF-2a, to bind to the VISTA promoter. The functional consequence of hypoxia-dependent induction of VISTA is the suppression of T cell proliferation and activity [39].

\section{Hypoxia Upregulates the Macrophage Immune Checkpoint CD47 “Don't Eat Me Signal” and Induces Tumor Cell Escape from Phagocytosis}

Cluster of differentiation 47 (CD47), also known as integrin-associated protein, is a transmembrane immune checkpoint protein expressed on the cell surface of tumor cells and hematopoietic cells [40]. Following the binding of CD47 to its ligands-signal regulatory protein $\alpha$ (SIRP $\alpha)$ and thrombospondin-1 (TSP-1) — on the surface of macrophages and dendritic cells, CD47 provides a robust "don't eat me signal" to block phagocytosis [41] (Figure 1C). The elevated expression level of CD47 is an adverse prognostic factor in acute myeloid leukemia [42]. Targeting CD47 for cancer therapy has sparked great interest. Clinically, the use of anti-CD47 5F9 appears to be safe and well tolerated in most patients. However, it should be highlighted that the most significant side effects of 5F9 are transient anemia, fatigue and headache. Mechanistically, very little is known about the molecular mechanisms underlying the transcriptional regulation of the CD47 gene. Nevertheless, several signaling pathways, transcription factors [43,44], and miRNA [45] have been reported to regulate the expression of CD47.

Several ICBs are currently being developed to specifically target and activate different innate immune cells, including macrophages and dendritic cells (DCs) [42,46]. Blockade of the CD47 "don't eat me signal" using monoclonal antibodies against CD47 increases macrophage-mediated phagocytosis and elimination of various solid tumors [41]. When using several tumor models syngenically transplanted into immune-competent mice, blocking CD47 promotes massive destruction of tumor cells by a mechanism mainly depending on $T$ lymphocytes activation [47]. Human CD47-blocking monoclonal antibodies have incredible efficacy in numerous patient-derived xenograft (PDX) preclinical models of breast, lymphoma, bladder, colon, glioblastoma, lung, acute lymphocytic leukemia, and acute myeloid leukemia [41,48,49]. CD47 blockade is, therefore, a novel validated target for macrophage-mediated ICB-based cancer immunotherapy.

Induction of phagocytosis by anti-CD47 blockade results in increased antigen uptake and presentation, thereby simultaneously enhancing innate and adaptive immune systems [50]. CD47 blocking therapy will, therefore, synergize with immune checkpoint inhibitors that target the adaptive immune system. Previous studies have established that both innate and adaptive immune systems are required for the complete therapeutic response of ICBs [51-53].

In breast cancer, evidence has been reported that hypoxia positively regulates the expression of CD47 by showing that the expression of CD47 is positively correlated with the expression of HIF- $1 \alpha$ downstream target genes [44]. In triple-negative breast cancer cells, HIF-1 $\alpha$ induced the expression of CD47, leading to cancer stem cell phenotype switch and cancer cell escape from phagocytosis, which was mediated by bone marrow-derived macrophages [44]. In pancreatic adenocarcinoma, hypoxia also upregulated the expression of CD47, thus blocking the pro-phagocytic signals in both MDSC and macrophages [54,55].

\section{Hypoxia-Induced Autophagy Impairs Tumor Cell Susceptibility to Immune Cell Attack}

Autophagy is a cellular pathway involved in the degradation of cellular components, including damaged organelles and misfolded proteins in the lysosomal compartment. Such degradation provides nutrients to maintain cellular functions under stress conditions, such as hypoxia [56]. Although the activation of autophagy by hypoxia in tumor cells can occur either in a HIF-1- dependent or HIF-1-independent manner, the major negative impact of hypoxia-induced autophagy on the anti-tumor 
immunity involves HIF-1 $\alpha$. Briefly, HIF- $1 \alpha$ induces the expression of the Bcl-2 homology (BH) 3-only protein Bcl-2/adenovirus E1B $19 \mathrm{kDa}$-interacting protein 3 (BNIP3) and the related protein, BNIP3L [57]. Under hypoxia, the BNIP3/BNIP3L complex activates autophagy by preventing the association between Beclin1 (BECN1) and B-cell lymphoma 2 (Bcl-2) [58]. We have previously reported that the susceptibility of lung cancer cells to CTL-mediated killing was dramatically impaired under hypoxia through the activation of autophagy. We show that inhibiting autophagy genes Beclin1 or ATG5 restored lung cancer cell susceptibility to CTL mediated lysis under hypoxic stress. The molecular mechanism underlying the restoration of CTL-mediated killing of lung cancer cells following autophagy blockade is related to the ability of tumor cells to induce ubiquitin-proteasome system (UPS)-dependent degradation of phospho-signal transducer and activator of transcription 3 (pSTAT3) [59,60]. In addition to the mechanism described above, hypoxia, via HIF-1, upregulates the expression of the stem cell self-renewal transcription factor Nanog Homeobox (NANOG) at both transcriptional and translational levels. HIF- $1 \alpha$ silencing is sufficient to downregulate hypoxia-dependent induction of NANOG. Genetic silencing of hypoxia-induced NANOG in tumor cells restored CTL-mediated tumor cell killing. The molecular mechanisms underlying NANOG-dependent inhibition of CTL-mediated killing involve STAT3 phosphorylation and its nuclear translocation as well as autophagy activation [61-63]. Furthermore, HIF- $1 \alpha$ also impairs the tumor cell susceptibility to CTL-mediated killing by inducing the expression of microRNA (miR)-210, which targets the non-receptor protein tyrosine phosphatase type 1 (PTPN1), homeobox A1 (HOXA1), and tumor protein p53-inducible protein 11 (TP53I11) [64].

The negative impact of hypoxia is not only restricted to the impairment of cancer cell susceptibility to CTL-mediated killing but also applies to Natural Killer cell (NK)-mediated killing. Evidence has been reported that hypoxia is involved in the shedding and in the downregulation of major histocompatibility complex (MHC) class I polypeptide-related sequence A (MICA), a ligand for the activating NKG2D receptor expressed on the surface of cancer cells. The shedding of MICA led to tumor cell escape from NK- and CTL-mediated killing [65-67].

Moreover, hypoxic tumor cells take advantage of the induction of autophagy to selectively degrade the serine protease granzyme B (GZMB) released by NK cells. The release of cytotoxic granules containing perforin (PRF1) and GZMB by NK cells is one of the major mechanisms responsible for tumor cell killing by NK cells. These cytotoxic granules enter target tumor cells by endocytosis and traffic to large specific endosomes named "gigantosomes". Evidence has been reported that the proapoptotic protein GZMB is selectively degraded by the activation of autophagy in hypoxic cells, thus inhibiting NK-mediated killing of cancer cells (Figure 1D). The mechanism by which autophagy selectively degrades granzyme B is not yet fully understood $[68,69]$.

\section{Hypoxia Upregulates the Expression of the Non-Classical and Immunosuppressive MHC Class I (HLA-G)}

HLA-G is a non-classical MHC-I molecule expressed in several tumor types including melanoma, glioblastoma, colorectal, ovarian and cervical tumors. HLA-G expression in tumors was related to advanced tumor stages, poor prognosis [70,71] and immune suppression [72,73]. The immunosuppressive functions of HLA-G relies on its ability to bind to ILT2, ILT4, and KIR2DL4 expressed by several immune cells, including B cells, T cells, NK, myelomonocytic cells, dendritic cells, monocytes, and macrophages [74,75] (Figure 1E). HLA-G is therefore proposed as an immune checkpoint [76] and an attractive therapeutic target [77]. Several HREs have been identified in the promoter of HLA-G $[78,79]$, indicating that the hypoxia-dependent mechanism underlying the expression of HLA-G most likely relies on the ability of HIF-1 to bind to HRE motifs and induce $H L A-G$ transcripts. 


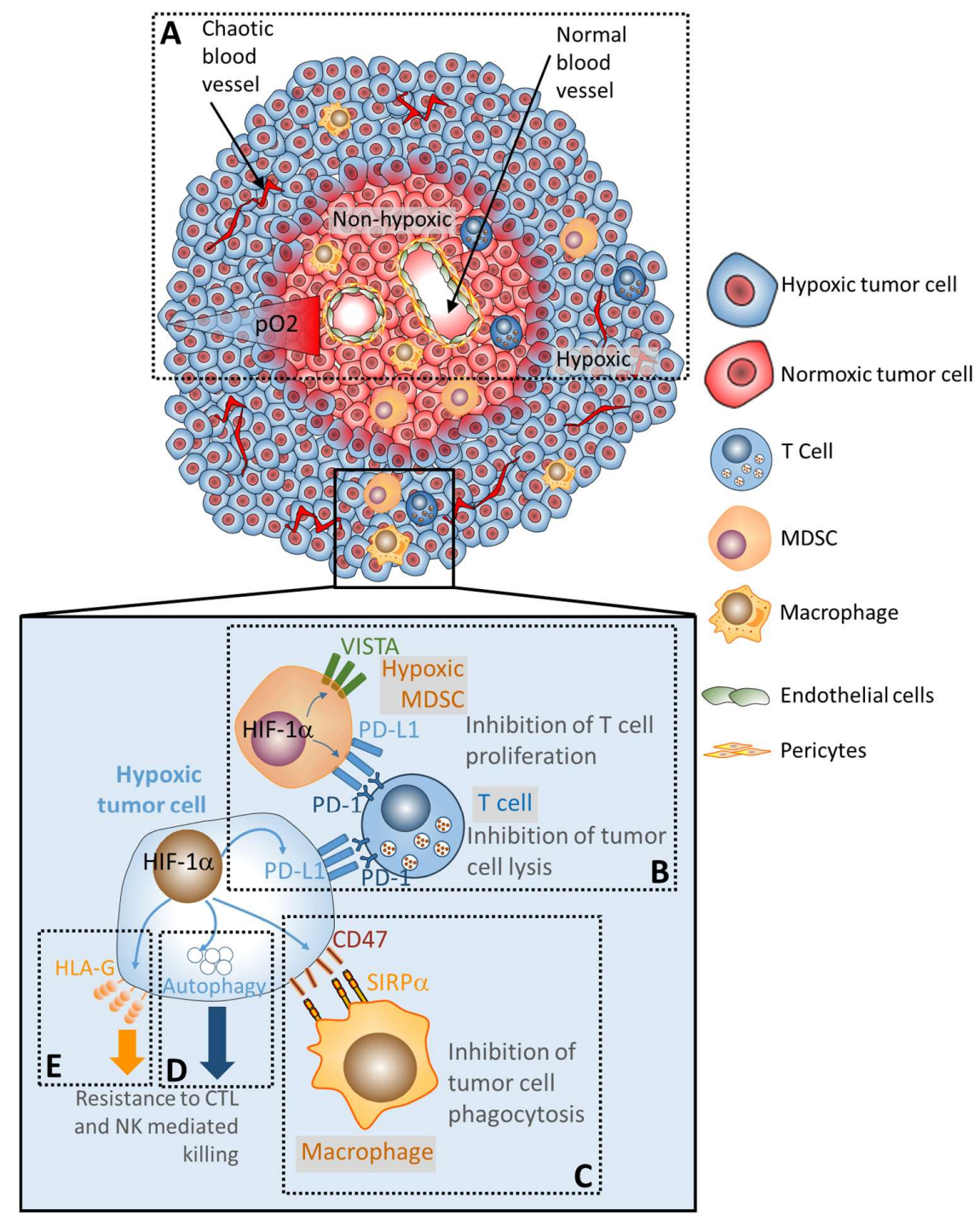

Figure 1. The hypoxic tumor microenvironment and its impact on anti-tumor immunity. (A) Hypoxia is established in the tumor microenvironment due to an increase in tumor cell proliferation, and a decrease in oxygen supply. Non-hypoxic tumor regions displayed normal blood vessels covered by well-organized endothelial cells and pericytes. In hypoxic tumor regions, the pressure of oxygen is low which arises from oxygen diffusion limitations due to disorganized, chaotic tumor microvasculature network with leaky vessels. (B) Under hypoxia, the stabilization of hypoxia-inducible factor (HIF)- $1 \alpha$ in cells upregulates the expression of PD-L1 in hypoxic tumor cells and PD-L1 and VISTA in hypoxic MDSCs. The increased expression of PD-L1 and VISTA results in an inhibition of T cell proliferation and $\mathrm{T}$ cell mediated lysis. (C) HIF-1 $\alpha$ is also involved in the upregulation of cluster of differentiation 47 (CD47) on the surface of tumor cells. Following the binding of CD47 to signal regulatory protein $\alpha(\operatorname{SIRP} \alpha)$, expressed on the surface of macrophages, tumor cells provide a strong "don't eat me signal" to block phagocytosis property of macrophages. (D) The activation of autophagy in hypoxic tumor cells impairs tumor cell susceptibility to CTL and NK-mediated lysis by at least two distinct mechanisms involving the degradation of NK-derived Granzyme B and the stabilization of pSTAT3. Other hypoxia-dependent, but autophagy-independent, mechanisms are described in this review including the overexpression of NANOG and miR-210 targeting PTPN1, HOXA1, and TP53I11. (E) Hypoxia upregulates the expression of HLA-G on the surface of tumor cells. The upregulated HLA-G binds to ILT2, ILT4 and KIR2DL4 expressed by several immune cells (B and T cells, NK cells, myelomonocytic cells, dendritic cells, monocytes and macrophages) leading to tumor escape from immune surveillance. 


\section{The Challenges and Opportunities of Targeting Hypoxia}

Our understanding of the molecular mechanisms underlying intratumoral hypoxia has largely fueled interest in the development of strategies to inhibit hypoxia in cancer therapy. However, the excitement for developing such strategies has been tempered by the lack of selectivity of HIF-1 inhibitors that might be thought of as a gold standard. Obviously, the unique opportunity for exploiting hypoxia inhibitors in the clinic is their validation in appropriate preclinical models and more importantly, in early clinical trials. Targeting hypoxia could be achieved using hypoxia-activated prodrug or drugs that directly or indirectly modulate HIFs. A hypoxia-activated prodrug is an inactive compound that can be converted to a pharmacologically active drug in hypoxic cells or tissues. The conversion is achieved by one electron cellular reductases to generate prodrug radical that can be further reoxidized to the initial prodrug in a non-hypoxic cell. The prodrug can also be converted (in a single step) into a cytotoxic drug via the two-electron reduction pathway [80]. The hypoxia prodrug tirapazamine and its analog SN30000, as well as TH-302 and apaziquone EO9, have been evaluated in clinical trials with some disappointments. However, the published results of the combination of TH-302 with gemcitabine in pancreatic cancer [81] or with doxorubicin in soft tissue sarcoma [82] in phase II clinical trials are encouraging. Recently, it has been reported that TH-302 significantly reduced hypoxia in a preclinical mouse prostate model. In addition, combining TH-302 therapy with T cell immune checkpoint blockades CTLA- 4 and PD- 1 cured more than $80 \%$ of tumors in a mouse prostate-derived model, most likely by driving an influx of $\mathrm{T}$ cells into hypoxic zones and by reducing both MDSC and granulocytic subsets in the microenvironment [83]. Although the clinical trials using EO9 were negative, the loco-regional administration of this drug in patients having superficial bladder cancer has shown efficacy. Based on these data, two phase III clinical trials (NCT00598806 and NCT00461591) have been performed using EO9 as adjuvant therapy in bladder cancer patients treated with surgery.

According to their mode of action, an increasing number of HIF modulating drugs are being reported. These drugs can be classified as modulators of the expression, translation, degradation, DNA binding, and transcriptional activity of HIF-proteins. Although several excellent reviews have provided a comprehensive overview of all drugs affecting hypoxia and detailed their mode of action [23,84-86], here we will summarize the major drugs modulating the expression of HIFs according to the three mechanisms of action described above.

The drugs directly modulating HIF-mRNA include HIF- $1 \alpha$ antisense oligonucleotides EZN-2698 [87], aminoflavone [88], and thioredoxin inhibitors (AJM290 and AW464) [89], although these particular drugs are also reported to stabilize HIF- $1 \alpha$ and HIF- $2 \alpha$. Several drugs targeting signaling pathways involved in the control of HIF- $1 \alpha$ mRNA translation have been identified, such as inhibitors of the PI3K/AKT/mTOR pathway [90-92]; topoisomerase 1 inhibitors (Irinotecan and Topotecan) [93,94]; and methoxyestradiol (2ME2) [95]. Drugs that induced HIF-1 $\alpha$ degradation include Geldanamycin analog 17-AAG (tanespimycin) and 17-DMAG (alvespimycin) [96]; the next-generation EC154 molecule [96]; HDAC inhibitors (vorinostat, romidepsin, panobinostat, and belinostat, which might also act as inhibitors of HIF-1 $\alpha$ translation) [97]; and the melphalan-derived alkylating agent PX-478 [98]. Drugs inhibiting the transcriptional activity of HIFs were also reported, such as FM19G11 [99], acriflavine [100], and PT2385, which inhibits the transcriptional activity of HIF-2 $\alpha$. Finally, chetomin has been reported to disrupt HIF-p300 interaction, thereby inhibiting HIF-DNA binding activity [101].

\section{Concluding Remarks}

While the hypoxic tumor microenvironment has long been considered as one of the most attractive targets in cancer drug development, numerous strategies and drugs described in this review have been suggested to target hypoxic tumor cells, including hypoxia-activated prodrugs, small HIFs inhibitors, or drugs targeting HIF-downstream signaling pathways $[85,102,103]$. Despite considerable efforts intended to bring hypoxia inhibitors to the clinic, there are so far no approved drugs that directly target hypoxia or HIF-dependent pathways, and the results from the various clinical trials have 
been mostly disappointing $[84,104]$. This could be, at least in part, attributed to the ability of HIF to control a highly complex network connecting several signaling pathways and various overlapping mechanisms in tumor cells and other cells in the tumor microenvironment. In addition, the lack of specificity of the majority of HIF inhibitors impedes the efficacy of these drugs and participates in the failure of clinical trials designed to include HIF-1 inhibitors. Nevertheless, recent discoveries showing that hypoxia negatively impacts the tumor immune response by modifying the expression of main immune checkpoints (e.g., PD-L1, CD47, PD-1, HLA-G, ... ) provide a major opportunity for innovative combination approaches. Such combinations might pave the way for setting up new strategies for therapeutic intervention to enhance the clinical benefit of immune checkpoint blockades in solid tumors. Future efforts should be focused on the development of potent and selective inhibitors of hypoxia, which is considered among the greatest challenges in cancer drug development.

Author Contributions: Writing-review and editing, B.J., M.Z.N., M.H., M.X., S.C., A.L., G.B. and C.D.; funding acquisition: B.J., M.Z.N. and G.B.

Funding: This research was funded by the Luxembourg National Research Fund (C18/BM/12670304/COMBATIC), and grants from FNRS Televie (7.4606.18; 7.4664.15; 7.4565.17; and 7.6505.18), National Research Fund (FNR) Luxembourg (grant no. FNR PRIDE15/10675146/CANBIO), Luxembourg Institute of Health (LECR 20170540), "Fondation Cancer", Luxembourg FC/2018/06; Kriibskrank Kanner Foundation, Janssen Cilag, and Action LIONS Vaincre le Cancer, Luxembourg.

Conflicts of Interest: The authors declare no conflict of interest.

\section{References}

1. Skrombolas, D.; Frelinger, J.G. Challenges and developing solutions for increasing the benefits of IL-2 treatment in tumor therapy. Expert Rev. Clin. Immunol. 2014, 10, 207-217. [CrossRef]

2. June, C.H. Adoptive T cell therapy for cancer in the clinic. J. Clin. Investig. 2007, 117, 1466-1476. [CrossRef]

3. Postow, M.A.; Callahan, M.K.; Wolchok, J.D. Immune Checkpoint Blockade in Cancer Therapy. J. Clin. 2015, 33, 1974-1982. [CrossRef]

4. Sharma, P.; Allison, J.P. The future of immune checkpoint therapy. Science 2015, 348, 56-61. [CrossRef]

5. Topalian, S.L.; Drake, C.G.; Pardoll, D.M. Immune checkpoint blockade: a common denominator approach to cancer therapy. Cancer Cell 2015, 27, 450-461. [CrossRef]

6. Smyth, M.J.; Ngiow, S.F.; Ribas, A.; Teng, M.W. Combination cancer immunotherapies tailored to the tumour microenvironment. Nat. Rev. Clin. Oncol. 2016, 13, 143-158. [CrossRef]

7. McArthur, H.L. Checkpoint inhibitors in breast cancer: hype or promise? Clin. Adv. Hematol. Oncol. 2016, 14, 392-395.

8. Khan, K.A.; Kerbel, R.S. Improving immunotherapy outcomes with anti-angiogenic treatments and vice versa. Nat. Rev. Clin. Oncol. 2018, 15, 310-324. [CrossRef]

9. Motzer, R.J.; Escudier, B.; McDermott, D.F.; George, S.; Hammers, H.J.; Srinivas, S.; Tykodi, S.S.; Sosman, J.A.; Procopio, G.; Plimack, E.R.; et al. Nivolumab versus Everolimus in Advanced Renal-Cell Carcinoma. N. Engl. J. Med. 2015, 373, 1803-1813. [CrossRef]

10. Wolchok, J.D.; Kluger, H.; Callahan, M.K.; Postow, M.A.; Rizvi, N.A.; Lesokhin, A.M.; Segal, N.H.; Ariyan, C.E.; Gordon, R.A.; Reed, K.; et al. Nivolumab plus ipilimumab in advanced melanoma. N. Engl. J. Med. 2013, 369, 122-133. [CrossRef]

11. Wolchok, J.D.; Chiarion-Sileni, V.; Gonzalez, R.; Rutkowski, P.; Grob, J.J.; Cowey, C.L.; Lao, C.D.; Wagstaff, J.; Schadendorf, D.; Ferrucci, P.F.; et al. Overall Survival with Combined Nivolumab and Ipilimumab in Advanced Melanoma. N. Engl. J. Med. 2017, 377, 1345-1356. [CrossRef]

12. Cooper, Z.A.; Frederick, D.T.; Ahmed, Z.; Wargo, J.A. Combining checkpoint inhibitors and BRAF-targeted agents against metastatic melanoma. Oncoimmunology 2013, 2, e24320. [CrossRef]

13. Buchbinder, E.I.; Hodi, F.S. Melanoma in 2015: Immune-checkpoint blockade-Durable cancer control. Nat. Rev. Clin. Oncol. 2016, 13, 77-78. [CrossRef]

14. Farkona, S.; Diamandis, E.P.; Blasutig, I.M. Cancer immunotherapy: The beginning of the end of cancer? BMC Med. 2016, 14, 73. [CrossRef] 
15. Tredan, O.; Galmarini, C.M.; Patel, K.; Tannock, I.F. Drug resistance and the solid tumor microenvironment. J. Natl. Cancer Inst. 2007, 99, 1441-1454. [CrossRef]

16. Jain, R.K. Normalizing tumor vasculature with anti-angiogenic therapy: A new paradigm for combination therapy. Nat. Med. 2001, 7, 987-989. [CrossRef]

17. Semenza, G.L. Hypoxia-inducible factors: Mediators of cancer progression and targets for cancer therapy. Trends Pharmacol. Sci. 2012, 33, 207-214. [CrossRef]

18. Semenza, G.L. Targeting HIF-1 for cancer therapy. Nat. Rev. Cancer 2003, 3, 721-732. [CrossRef]

19. Jewell, U.R.; Kvietikova, I.; Scheid, A.; Bauer, C.; Wenger, R.H.; Gassmann, M. Induction of HIF-1alpha in response to hypoxia is instantaneous. FASEB J. 2001, 15, 1312-1314. [CrossRef]

20. Semenza, G.L. A Compendium of Proteins that Interact with HIF-1alpha. Exp. Cell Res. 2017. [CrossRef]

21. Harris, A.L. Hypoxia-a key regulatory factor in tumour growth. Nat. Rev. Cancer 2002, 2, 38-47. [CrossRef]

22. Shannon, A.M.; Bouchier-Hayes, D.J.; Condron, C.M.; Toomey, D. Tumour hypoxia, chemotherapeutic resistance and hypoxia-related therapies. Cancer Treat Rev. 2003, 29, 297-307. [CrossRef]

23. Wilson, W.R.; Hay, M.P. Targeting hypoxia in cancer therapy. Nat. Rev. Cancer 2011, 11, 393-410. [CrossRef]

24. Lequeux, A.; Noman, M.Z.; Xiao, M.; Sauvage, D.; Van Moer, K.; Viry, E.; Bocci, I.; Hasmim, M.; Bosseler, M.; Berchem, G.; et al. Impact of hypoxic tumor microenvironment and tumor cell plasticity on the expression of immune checkpoints. Cancer Lett. 2019, 458, 13-20. [CrossRef]

25. Daniel, S.K.; Sullivan, K.M.; Labadie, K.P.; Pillarisetty, V.G. Hypoxia as a barrier to immunotherapy in pancreatic adenocarcinoma. Clin. Transl. Med. 2019, 8, 10. [CrossRef]

26. Chouaib, S.; Messai, Y.; Couve, S.; Escudier, B.; Hasmim, M.; Noman, M.Z. Hypoxia promotes tumor growth in linking angiogenesis to immune escape. Front. Immunol. 2012, 3, 21. [CrossRef]

27. Chouaib, S.; Janji, B.; Tittarelli, A.; Eggermont, A.; Thiery, J.P. Tumor plasticity interferes with anti-tumor immunity. Crit. Rev. Immunol. 2014, 34, 91-102. [CrossRef]

28. Hasmim, M.; Messai, Y.; Ziani, L.; Thiery, J.; Bouhris, J.H.; Noman, M.Z.; Chouaib, S. Critical Role of Tumor Microenvironment in Shaping NK Cell Functions: Implication of Hypoxic Stress. Front. Immunol. 2015, 6, 482. [CrossRef]

29. Noman, M.Z.; Hasmim, M.; Messai, Y.; Terry, S.; Kieda, C.; Janji, B.; Chouaib, S. Hypoxia: A key player in antitumor immune response. A Review in the Theme: Cellular Responses to Hypoxia. Am. J. Physiol. Cell Physiol. 2015, 309, C569-C579. [CrossRef]

30. Fridman, W.H.; Pages, F.; Sautes-Fridman, C.; Galon, J. The immune contexture in human tumours: Impact on clinical outcome. Nat. Rev. Cancer 2012, 12, 298-306. [CrossRef]

31. Whiteside, T.L. The tumor microenvironment and its role in promoting tumor growth. Oncogene 2008, 27, 5904-5912. [CrossRef]

32. Seidel, J.A.; Otsuka, A.; Kabashima, K. Anti-PD-1 and Anti-CTLA-4 Therapies in Cancer: Mechanisms of Action, Efficacy, and Limitations. Front. Oncol. 2018, 8, 86. [CrossRef]

33. Noman, M.Z.; Desantis, G.; Janji, B.; Hasmim, M.; Karray, S.; Dessen, P.; Bronte, V.; Chouaib, S. PD-L1 is a novel direct target of HIF-1alpha, and its blockade under hypoxia enhanced MDSC-mediated T cell activation. J. Exp. Med. 2014, 211, 781-790. [CrossRef]

34. Barsoum, I.B.; Smallwood, C.A.; Siemens, D.R.; Graham, C.H. A mechanism of hypoxia-mediated escape from adaptive immunity in cancer cells. Cancer Res. 2014, 74, 665-674. [CrossRef]

35. Messai, Y.; Gad, S.; Noman, M.Z.; Le Teuff, G.; Couve, S.; Janji, B.; Kammerer, S.F.; Rioux-Leclerc, N.; Hasmim, M.; Ferlicot, S.; et al. Renal Cell Carcinoma Programmed Death-ligand 1, a New Direct Target of Hypoxia-inducible Factor-2 Alpha, is Regulated by von Hippel-Lindau Gene Mutation Status. Eur. Urol. 2015. [CrossRef]

36. Noman, M.Z.; Chouaib, S. Targeting hypoxia at the forefront of anticancer immune responses. Oncoimmunology 2014, 3, e954463. [CrossRef]

37. Nowak, E.C.; Lines, J.L.; Varn, F.S.; Deng, J.; Sarde, A.; Mabaera, R.; Kuta, A.; Le Mercier, I.; Cheng, C.; Noelle, R.J. Immunoregulatory functions of VISTA. Immunol. Rev. 2017, 276, 66-79. [CrossRef]

38. Zou, W.; Chen, L. Inhibitory B7-family molecules in the tumour microenvironment. Nat. Rev. Immunol. 2008, 8, 467-477. [CrossRef]

39. Deng, J.; Li, J.; Sarde, A.; Lines, J.L.; Lee, Y.C.; Qian, D.C.; Pechenick, D.A.; Manivanh, R.; Le Mercier, I.; Lowrey, C.H.; et al. Hypoxia-Induced VISTA Promotes the Suppressive Function of Myeloid-Derived Suppressor Cells in the Tumor Microenvironment. Cancer Immunol. Res. 2019, 7, 1079-1090. [CrossRef] 
40. Jaiswal, S.; Jamieson, C.H.; Pang, W.W.; Park, C.Y.; Chao, M.P.; Majeti, R.; Traver, D.; van Rooijen, N.; Weissman, I.L. CD47 is upregulated on circulating hematopoietic stem cells and leukemia cells to avoid phagocytosis. Cell 2009, 138, 271-285. [CrossRef]

41. Willingham, S.B.; Volkmer, J.P.; Gentles, A.J.; Sahoo, D.; Dalerba, P.; Mitra, S.S.; Wang, J.; Contreras-Trujillo, H.; Martin, R.; Cohen, J.D.; et al. The CD47-signal regulatory protein alpha (SIRPa) interaction is a therapeutic target for human solid tumors. Proc. Natl. Acad. Sci. USA 2012, 109, 6662-6667. [CrossRef]

42. Majeti, R.; Chao, M.P.; Alizadeh, A.A.; Pang, W.W.; Jaiswal, S.; Gibbs, K.D., Jr.; van Rooijen, N.; Weissman, I.L. CD47 is an adverse prognostic factor and therapeutic antibody target on human acute myeloid leukemia stem cells. Cell 2009, 138, 286-299. [CrossRef]

43. Casey, S.C.; Tong, L.; Li, Y.; Do, R.; Walz, S.; Fitzgerald, K.N.; Gouw, A.M.; Baylot, V.; Gutgemann, I.; Eilers, M.; et al. MYC regulates the antitumor immune response through CD47 and PD-L1. Science 2016, 352, $227-231$. [CrossRef]

44. Zhang, H.; Lu, H.; Xiang, L.; Bullen, J.W.; Zhang, C.; Samanta, D.; Gilkes, D.M.; He, J.; Semenza, G.L. HIF-1 regulates CD47 expression in breast cancer cells to promote evasion of phagocytosis and maintenance of cancer stem cells. Proc. Natl. Acad. Sci. USA 2015, 112, E6215-E6223. [CrossRef]

45. Li, H.; Wang, Y.; Li, Y.-Z. MicroRNA-133a suppresses the proliferation, migration, and invasion of laryngeal carcinoma cells by targeting CD47. Tumor Biol. 2016, 37, 16103-16113. [CrossRef]

46. DeNardo, D.G.; Ruffell, B. Macrophages as regulators of tumour immunity and immunotherapy. Nat. Rev. Immunol. 2019, 19, 369-382. [CrossRef]

47. Liu, X.; Pu, Y.; Cron, K.; Deng, L.; Kline, J.; Frazier, W.A.; Xu, H.; Peng, H.; Fu, Y.X.; Xu, M.M. CD47 blockade triggers T cell-mediated destruction of immunogenic tumors. Nat. Med. 2015, 21, 1209-1215. [CrossRef]

48. Chao, M.P.; Alizadeh, A.A.; Tang, C.; Jan, M.; Weissman-Tsukamoto, R.; Zhao, F.; Park, C.Y.; Weissman, I.L.; Majeti, R. Therapeutic antibody targeting of CD47 eliminates human acute lymphoblastic leukemia. Cancer Res. 2011, 71, 1374-1384. [CrossRef]

49. Weiskopf, K.; Jahchan, N.S.; Schnorr, P.J.; Cristea, S.; Ring, A.M.; Maute, R.L.; Volkmer, A.K.; Volkmer, J.P.; Liu, J.; Lim, J.S.; et al. CD47-blocking immunotherapies stimulate macrophage-mediated destruction of small-cell lung cancer. J. Clin. Investig. 2016, 126, 2610-2620. [CrossRef]

50. Matlung, H.L.; Szilagyi, K.; Barclay, N.A.; van den Berg, T.K. The CD47-SIRPalpha signaling axis as an innate immune checkpoint in cancer. Immunol. Rev. 2017, 276, 145-164. [CrossRef]

51. Park, S.; Jiang, Z.; Mortenson, E.D.; Deng, L.; Radkevich-Brown, O.; Yang, X.; Sattar, H.; Wang, Y.; Brown, N.K.; Greene, M.; et al. The therapeutic effect of anti-HER2/neu antibody depends on both innate and adaptive immunity. Cancer Cell 2010, 18, 160-170. [CrossRef]

52. Kumar, V.; Gabrilovich, D.I. Hypoxia-inducible factors in regulation of immune responses in tumour microenvironment. Immunology 2014, 143, 512-519. [CrossRef]

53. Zhu, E.F.; Gai, S.A.; Opel, C.F.; Kwan, B.H.; Surana, R.; Mihm, M.C.; Kauke, M.J.; Moynihan, K.D.; Angelini, A.; Williams, R.T.; et al. Synergistic innate and adaptive immune response to combination immunotherapy with anti-tumor antigen antibodies and extended serum half-life IL-2. Cancer Cell 2015, 27, 489-501. [CrossRef]

54. Michaels, A.D.; Newhook, T.E.; Adair, S.J.; Morioka, S.; Goudreau, B.J.; Nagdas, S.; Mullen, M.G.; Persily, J.B.; Bullock, T.N.J.; Slingluff, C.L., Jr.; et al. CD47 Blockade as an Adjuvant Immunotherapy for Resectable Pancreatic Cancer. Clin. Cancer Res. 2018, 24, 1415-1425. [CrossRef]

55. Soto-Pantoja, D.R.; Terabe, M.; Ghosh, A.; Ridnour, L.A.; DeGraff, W.G.; Wink, D.A.; Berzofsky, J.A.; Roberts, D.D. CD47 in the tumor microenvironment limits cooperation between antitumor T-cell immunity and radiotherapy. Cancer Res. 2014, 74, 6771-6783. [CrossRef]

56. Klionsky, D.J.; Emr, S.D. Autophagy as a regulated pathway of cellular degradation. Science 2000, 290, 1717-1721. [CrossRef]

57. Mazure, N.M.; Pouyssegur, J. Hypoxia-induced autophagy: Cell death or cell survival? Curr. Opin. Cell Biol. 2010, 22, 177-180. [CrossRef]

58. Bellot, G.; Garcia-Medina, R.; Gounon, P.; Chiche, J.; Roux, D.; Pouyssegur, J.; Mazure, N.M. Hypoxia-induced autophagy is mediated through hypoxia-inducible factor induction of BNIP3 and BNIP3L via their BH3 domains. Mol. Cell. Biol. 2009, 29, 2570-2581. [CrossRef]

59. Noman, M.Z.; Janji, B.; Kaminska, B.; Van Moer, K.; Pierson, S.; Przanowski, P.; Buart, S.; Berchem, G.; Romero, P.; Mami-Chouaib, F.; et al. Blocking hypoxia-induced autophagy in tumors restores cytotoxic T-cell activity and promotes regression. Cancer Res. 2011, 71, 5976-5986. [CrossRef] 
60. Noman, M.Z.; Janji, B.; Berchem, G.; Mami-Chouaib, F.; Chouaib, S. Hypoxia-induced autophagy: A new player in cancer immunotherapy? Autophagy 2012, 8, 704-706. [CrossRef]

61. Hasmim, M.; Janji, B.; Khaled, M.; Noman, M.Z.; Louache, F.; Bordereaux, D.; Abderamane, A.; Baud, V.; Mami-Chouaib, F.; Chouaib, S. Cutting Edge: NANOG Activates Autophagy under Hypoxic Stress by Binding to BNIP3L Promoter. J. Immunol. 2017, 198, 1423-1428. [CrossRef]

62. Hasmim, M.; Noman, M.Z.; Lauriol, J.; Benlalam, H.; Mallavialle, A.; Rosselli, F.; Mami-Chouaib, F.; Alcaide-Loridan, C.; Chouaib, S. Hypoxia-dependent inhibition of tumor cell susceptibility to CTL-mediated lysis involves NANOG induction in target cells. J. Immunol. 2011, 187, 4031-4039. [CrossRef]

63. Hasmim, M.; Noman, M.Z.; Messai, Y.; Bordereaux, D.; Gros, G.; Baud, V.; Chouaib, S. Cutting edge: Hypoxia-induced Nanog favors the intratumoral infiltration of regulatory $\mathrm{T}$ cells and macrophages via direct regulation of TGF-beta1. J. Immunol. 2013, 191, 5802-5806. [CrossRef]

64. Noman, M.Z.; Buart, S.; Romero, P.; Ketari, S.; Janji, B.; Mari, B.; Mami-Chouaib, F.; Chouaib, S. Hypoxia-inducible miR-210 regulates the susceptibility of tumor cells to lysis by cytotoxic T cells. Cancer Res. 2012, 72, 4629-4641. [CrossRef]

65. Barsoum, I.B.; Hamilton, T.K.; Li, X.; Cotechini, T.; Miles, E.A.; Siemens, D.R.; Graham, C.H. Hypoxia induces escape from innate immunity in cancer cells via increased expression of ADAM10: Role of nitric oxide. Cancer Res. 2011, 71, 7433-7441. [CrossRef]

66. Siemens, D.R.; Hu, N.; Sheikhi, A.K.; Chung, E.; Frederiksen, L.J.; Pross, H.; Graham, C.H. Hypoxia increases tumor cell shedding of MHC class I chain-related molecule: Role of nitric oxide. Cancer Res. 2008, 68, 4746-4753. [CrossRef]

67. Yamada, N.; Yamanegi, K.; Ohyama, H.; Hata, M.; Nakasho, K.; Futani, H.; Okamura, H.; Terada, N. Hypoxia downregulates the expression of cell surface MICA without increasing soluble MICA in osteosarcoma cells in a HIF-1alpha-dependent manner. Int. J. Oncol. 2012, 41, 2005-2012. [CrossRef]

68. Baginska, J.; Viry, E.; Berchem, G.; Poli, A.; Noman, M.Z.; van Moer, K.; Medves, S.; Zimmer, J.; Oudin, A.; Niclou, S.P.; et al. Granzyme B degradation by autophagy decreases tumor cell susceptibility to natural killer-mediated lysis under hypoxia. Proc. Natl. Acad. Sci. USA 2013, 110, 17450-17455. [CrossRef]

69. Viry, E.; Baginska, J.; Berchem, G.; Noman, M.Z.; Medves, S.; Chouaib, S.; Janji, B. Autophagic degradation of GZMB/granzyme B: A new mechanism of hypoxic tumor cell escape from natural killer cell-mediated lysis. Autophagy 2014, 10, 173-175. [CrossRef]

70. Andersson, E.; Poschke, I.; Villabona, L.; Carlson, J.W.; Lundqvist, A.; Kiessling, R.; Seliger, B.; Masucci, G.V. Non-classical HLA-class I expression in serous ovarian carcinoma: Correlation with the HLA-genotype, tumor infiltrating immune cells and prognosis. Oncoimmunology 2016, 5, e1052213. [CrossRef]

71. Mouillot, G.; Marcou, C.; Zidi, I.; Guillard, C.; Sangrouber, D.; Carosella, E.D.; Moreau, P. Hypoxia modulates HLA-G gene expression in tumor cells. Hum. Immunol. 2007, 68, 277-285. [CrossRef]

72. Kren, L.; Slaby, O.; Muckova, K.; Lzicarova, E.; Sova, M.; Vybihal, V.; Svoboda, T.; Fadrus, P.; Lakomy, R.; Vanhara, P.; et al. Expression of immune-modulatory molecules HLA-G and HLA-E by tumor cells in glioblastomas: An unexpected prognostic significance? Neuropathology 2011, 31, 129-134. [CrossRef]

73. Yan, W.H. HLA-G expression in cancers: Potential role in diagnosis, prognosis and therapy. Endocr. Metab. Immune Disord. Drug Targets 2011, 11, 76-89. [CrossRef]

74. Carosella, E.D.; Favier, B.; Rouas-Freiss, N.; Moreau, P.; Lemaoult, J. Beyond the increasing complexity of the immunomodulatory HLA-G molecule. Blood 2008, 111, 4862-4870. [CrossRef]

75. Amodio, G.; Sales de Albuquerque, R.; Gregori, S. New insights into HLA-G mediated tolerance. Tissue Antigens 2014, 84, 255-263. [CrossRef]

76. Carosella, E.D.; Rouas-Freiss, N.; Tronik-Le Roux, D.; Moreau, P.; LeMaoult, J. HLA-G: An Immune Checkpoint Molecule. Adv. Immunol. 2015, 127, 33-144. [CrossRef]

77. Curigliano, G.; Criscitiello, C.; Gelao, L.; Goldhirsch, A. Molecular pathways: Human leukocyte antigen G (HLA-G). Clin. Cancer Res. 2013, 19, 5564-5571. [CrossRef]

78. Yaghi, L.; Poras, I.; Simoes, R.T.; Donadi, E.A.; Tost, J.; Daunay, A.; de Almeida, B.S.; Carosella, E.D.; Moreau, P. Hypoxia inducible factor-1 mediates the expression of the immune checkpoint HLA-G in glioma cells through hypoxia response element located in exon 2. Oncotarget 2016, 7, 63690-63707. [CrossRef]

79. Garziera, M.; Scarabel, L.; Toffoli, G. Hypoxic Modulation of HLA-G Expression through the Metabolic Sensor HIF-1 in Human Cancer Cells. J. Immunol. Res. 2017, 2017, 4587520. [CrossRef] 
80. Baran, N.; Konopleva, M. Molecular Pathways: Hypoxia-Activated Prodrugs in Cancer Therapy. Clin. Cancer Res. 2017, 23, 2382-2390. [CrossRef]

81. Borad, M.J.; Reddy, S.G.; Bahary, N.; Uronis, H.E.; Sigal, D.; Cohn, A.L.; Schelman, W.R.; Stephenson, J., Jr.; Chiorean, E.G.; Rosen, P.J.; et al. Randomized Phase II Trial of Gemcitabine Plus TH-302 Versus Gemcitabine in Patients With Advanced Pancreatic Cancer. J. Clin. Oncol. 2015, 33, 1475-1481. [CrossRef]

82. Chawla, S.P.; Cranmer, L.D.; Van Tine, B.A.; Reed, D.R.; Okuno, S.H.; Butrynski, J.E.; Adkins, D.R.; Hendifar, A.E.; Kroll, S.; Ganjoo, K.N. Phase II study of the safety and antitumor activity of the hypoxia-activated prodrug TH-302 in combination with doxorubicin in patients with advanced soft tissue sarcoma. J. Clin. Oncol. 2014, 32, 3299-3306. [CrossRef]

83. Jayaprakash, P.; Ai, M.; Liu, A.; Budhani, P.; Bartkowiak, T.; Sheng, J.; Ager, C.; Nicholas, C.; Jaiswal, A.R.; Sun, Y.; et al. Targeted hypoxia reduction restores $\mathrm{T}$ cell infiltration and sensitizes prostate cancer to immunotherapy. J. Clin. Investig. 2018, 128, 5137-5149. [CrossRef]

84. Onnis, B.; Rapisarda, A.; Melillo, G. Development of HIF-1 inhibitors for cancer therapy. J. Cell. Mol. Med. 2009, 13, 2780-2786. [CrossRef]

85. Wigerup, C.; Pahlman, S.; Bexell, D. Therapeutic targeting of hypoxia and hypoxia-inducible factors in cancer. Pharmacol. Ther. 2016, 164, 152-169. [CrossRef]

86. Li, Y.; Patel, S.P.; Roszik, J.; Qin, Y. Hypoxia-Driven Immunosuppressive Metabolites in the Tumor Microenvironment: New Approaches for Combinational Immunotherapy. Front. Immunol. 2018, 9, 1591. [CrossRef]

87. Greenberger, L.M.; Horak, I.D.; Filpula, D.; Sapra, P.; Westergaard, M.; Frydenlund, H.F.; Albaek, C.; Schroder, H.; Orum, H. A RNA antagonist of hypoxia-inducible factor-1alpha, EZN-2968, inhibits tumor cell growth. Mol. Cancer Ther. 2008, 7, 3598-3608. [CrossRef]

88. Terzuoli, E.; Puppo, M.; Rapisarda, A.; Uranchimeg, B.; Cao, L.; Burger, A.M.; Ziche, M.; Melillo, G. Aminoflavone, a ligand of the aryl hydrocarbon receptor, inhibits HIF-1alpha expression in an AhR-independent fashion. Cancer Res. 2010, 70, 6837-6848. [CrossRef]

89. Jones, D.T.; Pugh, C.W.; Wigfield, S.; Stevens, M.F.; Harris, A.L. Novel thioredoxin inhibitors paradoxically increase hypoxia-inducible factor-alpha expression but decrease functional transcriptional activity, DNA binding, and degradation. Clin. Cancer Res. 2006, 12, 5384-5394. [CrossRef]

90. Hudson, C.C.; Liu, M.; Chiang, G.G.; Otterness, D.M.; Loomis, D.C.; Kaper, F.; Giaccia, A.J.; Abraham, R.T. Regulation of hypoxia-inducible factor 1alpha expression and function by the mammalian target of rapamycin. Mol. Cell. Biol. 2002, 22, 7004-7014. [CrossRef]

91. Thomas, G.V.; Tran, C.; Mellinghoff, I.K.; Welsbie, D.S.; Chan, E.; Fueger, B.; Czernin, J.; Sawyers, C.L. Hypoxia-inducible factor determines sensitivity to inhibitors of mTOR in kidney cancer. Nat. Med. 2006, 12, 122-127. [CrossRef]

92. Majumder, P.K.; Febbo, P.G.; Bikoff, R.; Berger, R.; Xue, Q.; McMahon, L.M.; Manola, J.; Brugarolas, J.; McDonnell, T.J.; Golub, T.R.; et al. mTOR inhibition reverses Akt-dependent prostate intraepithelial neoplasia through regulation of apoptotic and HIF-1-dependent pathways. Nat. Med. 2004, 10, 594-601. [CrossRef]

93. Rapisarda, A.; Uranchimeg, B.; Scudiero, D.A.; Selby, M.; Sausville, E.A.; Shoemaker, R.H.; Melillo, G. Identification of small molecule inhibitors of hypoxia-inducible factor 1 transcriptional activation pathway. Cancer Res. 2002, 62, 4316-4324.

94. Rapisarda, A.; Zalek, J.; Hollingshead, M.; Braunschweig, T.; Uranchimeg, B.; Bonomi, C.A.; Borgel, S.D.; Carter, J.P.; Hewitt, S.M.; Shoemaker, R.H.; et al. Schedule-dependent inhibition of hypoxia-inducible factor-1alpha protein accumulation, angiogenesis, and tumor growth by topotecan in U251-HRE glioblastoma xenografts. Cancer Res. 2004, 64, 6845-6848. [CrossRef]

95. Mabjeesh, N.J.; Escuin, D.; LaVallee, T.M.; Pribluda, V.S.; Swartz, G.M.; Johnson, M.S.; Willard, M.T.; Zhong, H.; Simons, J.W.; Giannakakou, P. 2ME2 inhibits tumor growth and angiogenesis by disrupting microtubules and dysregulating HIF. Cancer Cell 2003, 3, 363-375. [CrossRef]

96. Bohonowych, J.E.; Peng, S.; Gopal, U.; Hance, M.W.; Wing, S.B.; Argraves, K.M.; Lundgren, K.; Isaacs, J.S. Comparative analysis of novel and conventional Hsp90 inhibitors on HIF activity and angiogenic potential in clear cell renal cell carcinoma: Implications for clinical evaluation. BMC Cancer 2011, 11, 520. [CrossRef]

97. Hutt, D.M.; Roth, D.M.; Vignaud, H.; Cullin, C.; Bouchecareilh, M. The histone deacetylase inhibitor, Vorinostat, represses hypoxia inducible factor 1 alpha expression through translational inhibition. PLoS ONE 2014, 9, e106224. [CrossRef] 
98. Koh, M.Y.; Spivak-Kroizman, T.; Venturini, S.; Welsh, S.; Williams, R.R.; Kirkpatrick, D.L.; Powis, G. Molecular mechanisms for the activity of PX-478, an antitumor inhibitor of the hypoxia-inducible factor-1alpha. Mol. Cancer Ther. 2008, 7, 90-100. [CrossRef]

99. Moreno-Manzano, V.; Rodriguez-Jimenez, F.J.; Acena-Bonilla, J.L.; Fustero-Lardies, S.; Erceg, S.; Dopazo, J.; Montaner, D.; Stojkovic, M.; Sanchez-Puelles, J.M. FM19G11, a new hypoxia-inducible factor (HIF) modulator, affects stem cell differentiation status. J. Biol. Chem. 2010, 285, 1333-1342. [CrossRef]

100. Lee, K.; Zhang, H.; Qian, D.Z.; Rey, S.; Liu, J.O.; Semenza, G.L. Acriflavine inhibits HIF-1 dimerization, tumor growth, and vascularization. Proc. Natl. Acad. Sci. USA 2009, 106, 17910-17915. [CrossRef]

101. Cook, K.M.; Hilton, S.T.; Mecinovic, J.; Motherwell, W.B.; Figg, W.D.; Schofield, C.J. Epidithiodiketopiperazines block the interaction between hypoxia-inducible factor-1alpha (HIF-1alpha) and p300 by a zinc ejection mechanism. J. Biol. Chem. 2009, 284, 26831-26838. [CrossRef]

102. Chan, M.C.; Holt-Martyn, J.P.; Schofield, C.J.; Ratcliffe, P.J. Pharmacological targeting of the HIF hydroxylases-A new field in medicine development. Mol. Asp. Med. 2016, 47-48, 54-75. [CrossRef]

103. Haase, V.H. Therapeutic targeting of the HIF oxygen-sensing pathway: Lessons learned from clinical studies. Exp. Cell Res. 2017, 356, 160-165. [CrossRef]

104. Yu, T.; Tang, B.; Sun, X. Development of Inhibitors Targeting Hypoxia-Inducible Factor 1 and 2 for Cancer Therapy. Yonsei Med. J. 2017, 58, 489-496. [CrossRef]

(C) 2019 by the authors. Licensee MDPI, Basel, Switzerland. This article is an open access article distributed under the terms and conditions of the Creative Commons Attribution (CC BY) license (http://creativecommons.org/licenses/by/4.0/). 